\title{
PESSOA, Fernando. Escritos sobre metafísica e arte. Organização, introdução e notas de Cláudia Franco Souza e Nuno Ribeiro. Editora UFMG: Belo Horizonte, 2017. 129 p.
}

Tiago Cabral Vieira de Carvalho

Universidade Federal de Minas Gerais, Belo Horizonte, Minas Gerais / Brasil tiagocabralvieira@gmail.com

Recebido em $1^{\circ}$ de julho de 2017

Aprovado em 23 de janeiro de 2018

Escritos sobre metafísica e arte é uma coleção de nove textos (ou conjunto de ensaios) selecionados dentre a vasta obra teórica e filosófica deixada por Fernando Pessoa. Organizado por Cláudia Souza e Nuno Ribeiro, o livro reúne textos de autoria de três "eus" pessoanos, a saber, Álvaro de Campos, Ricardo Reis e Antônio Mora, além de textos sem assinatura, cuja autoria é atribuída ao próprio ortônimo.

Três textos do ortônimo compõem o livro. No primeiro, "Teorias metafísicas...", ele expõe sua desconfiança da validade de tais teorias e revela possuir uma sensibilidade ontológica bastante semelhante àquela da religião grega antiga, em que o acaso, metaforicamente representado por figuras mitológicas, rege nossas vidas. No segundo texto, "Atena", expressa sua visão, de forma geral, sobre arte. Pessoa elabora uma explicaçãopara a produção da arte com base na significação que têm Apolo - a junção "instintiva da sensibilidade com o entendimento, em cuja ação a arte tem origem como beleza" - e Atena - "a união da arte e da ciência, em cujo efeito a arte (...) tem origem como perfeição". Pessoa desenvolve esse raciocínio para concluir que a "arte é uma expressão 
de um equilíbrio entre a subjetividade da emoção e a objetividade do entendimento" (p. 34). Por fim, "Dividiu Aristóteles a poesia..." é um texto em que Pessoa fala sobre o seu "drama em gente". Ele explica que um poeta, por meio de um processo gradativo de despersonalização, é capaz de criar diversas vozes poéticas, completamente diferentes entre si, de tal forma que a poesia lírica culmina em poesia dramática, sem, todavia, ter a forma de drama. Portanto, conclui Pessoa, não há que buscar em quaisquer dos heterônimos ideias ou sentimentos seus, pois muitos deles exprimem ideias que não aceita, sentimentos que nunca teve.

Nos dois textos de Álvaro de Campos, o heterônimo discorda publicamente de seu criador. Em "O que é metafísica?", Campos afirma que a filosofia (tomada, no texto, por metafísica), tem o status de ciência virtual. Ele, entretanto, argumenta que tal status não merece ser desaproveitado e propõe que a metafísica seja arte.Em "Apontamentos para uma estética não-aristotélica", Campos insiste que a teoria da estética clássica não pode ser considerada a única certa. Ele explica, então, que sua concepção estética se baseia numa ideia de força, contrariamente à aristotélica - que tem a beleza como princípio fulcral - e quetal força, quando alcança o âmbito particular, tem o poder de subjugar. Portanto, ao contrário do artista aristotélico, que torna sua própria sensibilidade "humana e universal (...) para a poder tornar acessível e agradável, e assim poder captar os outros" (p. 97), o artista não-aristotélico de Campos lança mão de uma força que "force os outros, queiram eles ou não", a partilhar de sua sensibilidade particular.

Dois textos de Ricardo Reis estão presentes no livro. "Textos sobre arte" reúne alguns excertos acerca dos seus conceitos da arte e da beleza, que são deliberadamente clássicos. Usando um exemplo da poesia de Teixeira de Pascoaes, Reis apontapara uma mistura inapropriada de metáforas. $\mathrm{O}$ heterônimo argumenta que tal mistura pode até ser bela, mas é um "belo doentio e anormal", "sem poder de eternidade" pois as "obras eternas são serenas, lúcidas e racionais".Discute, ainda, a relação entre tradição e originalidade, e conclui que esta não existesem que haja uma relação intrínseca com a aquela.Em "Textos sobre metafísica, ciência e religião", apresenta ferrenhas críticas à religião. Afirma que esta, por ser uma metafísica ilegítima ou popular e que seus alicerces morais são relativos e, portanto, não transcendentais. Reis, no entanto, não defende que "se deve ir abalar a crença a um ignorante. Deve-se instruí-lo", pois a "instrução lhe abalará a crença." 
"Polêmica entre Ricardo Reis e Álvaro de Campos" reúne textos, de autoria dos dois heterônimos, que apresentam reflexões sobre arte de forma geral. Para Reis, há "só duas artes verdadeiras: a Poesia e a Escultura" e "o canto é a forma primitiva da poesia, porque é não a primeira forma de poesia, senão o caminho para ela”. Para Campos, há "cinco artes - a Literatura, a Engenharia, a Política, a Figuração e a Decoração" e a poesia é "cantar sem música." Reis argumenta que os poemas de Campos são um "extravasar de emoção" e que Campos, "quando escreve em verso", verdadeiramente escreve "prosa ritmada com pausas maiores." Por fim, Reis alega que a "arte existe, não como quer Campos, para substituir a vida, senão para a completar" (p. 118).

"Introdução ao estudo da metafísica", é o único texto de autoria de Antônio Mora. Neste longo conjunto de ensaios, Moraapresenta discussões acerca dos mais variados temas dentro do âmbito da metafísica, como a irredutibilidade do pensamento, a relação entre matéria e consciência, a natureza do tempo, o conflito entre consciência e existência, a natureza do senso moral, e a relação da atividade filosófica com a atividade propriamente científica. Mas apresenta também, ainda que brevemente, definições de conceitos estéticos. A arte, segundo Mora, seria o mais elevado modo de repouso do espírito.

Após a exposição dos pensamentos dos "eus" pessoanos, podemos perceber que as diferentes perspectivas de cada um mostram a capacidade de despersonalização de Pessoa. E ainda que as visões de alguns deles sobre temas específicos sejam semelhantes - como, por exemplo, o entendimento estético de Reise do ortônimo -, cada uma das vozes pessoanas adquire uma configuração única. Como bem apontam Souza e Ribeiro, a "noção de drama em gente apresentada na 'Tábua bibliográfica' clarifica a forma como Fernando Pessoa concebe a construção da sua escrita pluralista. (...) Há (...) um diálogo não somente literário, mas sobretudo filosófico ente os heterônimos, que irá estruturar esse drama em gente" (p. 20). Esse diálogo filosófico entre as múltiplas vozes pessoanas acrescenta ainda mais valor ao conjunto da obra de Fernando Pessoa, cuja rica obra poética já é bastante conhecida. 